\title{
Phenomenology, Community, Participation: A Critical Analysis of Wojtyła's Early Theory of Solidarity
}

\author{
WITOLD PŁOTKA
}

Institute of Philosophy, Cardinal Stefan Wyszynski University in Warsaw, 1/3 Wóycickiego Street, Building 23, PL-01-938 Warsaw, Poland Email:witoldplotka@gmail.com; w.plotka@uksw.edu.pl

\begin{abstract}
This article critically examines Wojtyła's early theory of solidarity in order to explore main concepts, methods and problems of his phenomenology of solidary actions. By Wojtyła's 'early theory' of solidarity is to be understood his theory formulated in The Acting Person and in the studies connected to the book, published mainly in the 1970's. The author argues that in his theory Wojtyła describes the first-person account of the experience of solidarity, by exploring how solidarity as a social phenomenon is experienced. In a word, the aim of the article consists in the analysis of Wojtyła's phenomenology of solidarity. To held this analysis, first, the author explores Wojtyła's methodology, i.e. Thomism, his understanding of phenomenology, and of experience. In this regard, the author asks which methodological attitude is adequate for describing solidarity. Second, Wojtyła's social ontology is reconstructed. His theory is labelled as adverbial social ontology since it accounts for community as a dynamic structure, which unites people who act 'together'. Finally, the author tracks main points of Wojtyła's view of participation as a social phenomenon which grounds solidarity.
\end{abstract}

Keywords: phenomenological method, community, social ontology, joint actions, personalism, Wojtyła

\section{INTRODUCTION}

This article is an attempt at a phenomenology of solidarizing understood in a broad sense as a subjective, or - more precisely - as a first-person account of the phenomenon of solidarity. By doing a phenomenology of solidarizing, then, one explores how solidarity is subjectively experienced or lived through. In turn, solidarity, generally speaking, is a social phenomenon, which consists in interpersonal or social relations that unite a group of people to undertake joint actions (e.g. one protests with the others against the government), or to share common believes (e.g. one solidarizes with crime victims by believing that violence is unacceptable). As such, of course, solidarity has its history - exemplified by many social movements - deeply rooted in intellectual history of the West. This study, however, does not develop these historical, though well explored issues (see, e.g. Stjernø 2005; Schmale 2017; Tiedemann 2018: 1-4). It does not aim at contributing to the normative concept of solidarity explored in political thought (see, e.g. Lesch 2018). Rather, its main aim is to elaborate 
the central topics connected with a phenomenology of solidarizing, such as its methodology and theoretical background in the concept of a subject or an agent, its social ontology, and a concrete description of the first-person perspective on solidarity. Here, then, the descriptive meaning of solidarity goes to the fore, and in this regard the aim here is to identify the mutual connections between the subjects understood as the members of a group. ${ }^{1}$ Given, however, that one of the main problems of such an attitude consists in a possible shift from a subjective experience to the intersubjective realization of solidarity - what is called the bridge problem (see Płotka 2018) - the article undertakes the question of how, if at all, phenomenology is able to overcome the bridge problem in the studies of solidarity. In this regard, it is claimed that Karol Wojtyła's (Pope John Paul II) early theory of solidarity gives us some clues about how to omit the problem by referring to the phenomenon of participation as a part of communal or joint actions. Yet, this theory also has some flaws. Thus, by offering a critical reading of Wojtyła's early theory of solidarity, the article attempts to question the limits and possibilities of a phenomenology of solidarity within the context of the bridge problem.

Nonetheless, given the complexity of Wojtyła's theory of solidarity and his commitments to the phenomenological movement in Poland, three preliminary remarks and restrictions are necessary. First of all, it is well known (McLean 1994: viii-ix) that Wojtyła was involved (to some extent) in the social movement of the labour union NSZZ 'Solidarność inspiring some philosophers, e.g. Józef Tischner, to use, or refer to phenomenology in the context of solidarity. The question of Wojtyła's contribution to these issues, however, is beyond my interests here (see, e.g. Szostek 1994: 67; Gubser 2014: 208-209). Second, Wojtyła's theory of solidarity is complex, and it is connected with the Catholic social teaching (see Doran 1996; Carney 2008). After all, it was also developed beyond phenomenological contexts after he became Pope in 1978, i.e. as the official doctrine of Catholic social teaching. In this regard, the article does not explore this later account of solidarity developed in encyclics, e.g. in Laborem Exercens (from 1981), but mostly in Sollicitudo Rei Socialis (from 1987) (see Johannes Paul II 1988). In turn, finally, by Wojtyła's 'early theory' of solidarity is understood his philosophical stance elaborated in his Lublin lectures (given from 1954 to 1957) on consciousness of values (Wojtyła 2006), his studies on Scheler, summarized in the form of the habilitation thesis (Wojtyła 2001: 11-128) and fully developed in The Acting Person (Wojtyła 1979a) - originally published in Polish as Osoba i czyn in 1969 - as well as in shorter pieces connected to this book (e.g. Wojtyła 1976, 1977, 1978, 1979b, 1993). ${ }^{2}$ One can argue that the 'early theory', so understood, is strictly connected with Wojtyła's early commitments to phenomenology.

To show how this early theory contributes to a phenomenology of solidarity, first, I explore Wojtyła's methodology in his view of (a) Thomism in its relation to (b) phenomenology, and I analyse the connection between these two methods by (c) examining his strong emphasis on experience. Wojtyła's philosophical position can be understood as a fusion of Thomistic

1 A descriptive meaning of solidarity is defined by Tiedemann (2018:1) as contrasted with its normative meaning as follows: 'Solidarity has a descriptive and a normative meaning. Descriptively it refers to the mutual connection between the members of a group that gives stability to the continuity of the group (cement of the society). Normatively it refers to the expectation of mutual support and the willingness of the group members to support the others or to contribute to a common good.'

2 For an overview of Wojtyła's early philosophy, and his way to phenomenology, see Buttiglione 1997: $44-176$. 
(objective) and phenomenological (subjective) approaches. At the same time, I argue that the Thomistic approach is inactive in Wojtyła's analysis of solidarity for different reasons and because of this, it does not solve the bridge problem. In turn, Wojtyła proposes to describe direct and intuitive experiences of solidarity. I term this approach a 'minimal phenomenology'. Next, I analyse components of Wojtyła's social ontology. Since he comprehends community as a factor which unites persons, at the beginning of the second part of the article, I summarize his view of the subject as an acting person. From within this background, I differentiate the interpersonal dimension, and the social dimension of community and I argue that community is constituted as 'we' in joint actions, which unite a multiplicity of subjects. Finally, I describe participation as a way of experiencing community. My ultimate thesis in this context is that participation refers to the very heart of experiencing solidarity.

\section{THE QUESTION OF METHOD: HOW TO ANALYSE SOLIDARITY?}

Given that Wojtyła's early philosophy can be regarded - as Burgos (2009: 109) rightly puts it - as an attempt to 're-found Thomistic anthropology in the light of phenomenology's, his method combines few diverse, though intertwined perspectives. In this regard, one can identify (a) Thomistic approach, (b) phenomenology, and - what is connected to phenomenology, but earlier than Wojtyła's explicit turn to phenomenology - (c) his analysis of experience. It is worth to shed more light on these three elements in order to ask later what enables Wojtyła to analyse solidarity.

By adopting Thomism, Wojtyła (2006: 62) assumes that only the Thomistic theory of being and metaphysical theses connected to the theory guarantee objectivity. Here, one is able to state that being truly exists despite the ways we experience it. After all, for Aquinas, according to Wojtyła (2001: 234), existence (esse) is the ground of being, and, conversely, it is unjustified to think that there is a being without existence. What lacks, however, in this approach is an adequate view of the person as a dynamic and subjective being. In a word, Thomism, which draws attention to objectivity, does not account for subjectivity and as such it cannot provide a justified basis for personalism. This is the reason why phenomenology, which enables one to investigate subjective experience - what finally enables studies on a personal being - seems to overcome the limitations of Thomism. Phenomenology, generally speaking, explores, following Wojtyła (2006: 23), essences given directly in eidetic intuition (Wesenschau). Essences, in turn, are distilled from intentional acts which are directed toward immanent contents. Moreover, phenomenology cannot be understood as a form of introspection since introspection is the method of psychology which concerns factual changes of a concrete person (Wojtyła 2001: 15). Phenomenology, then, is direct, intuitive, and concerns material a priori. To be precise, of course, phenomenology does not substitute for Wojtyła Thomism since just as Thomism is focused exclusively on objectivity, phenomenology accentuates subjectivity. Wojtyła (2001: 55, 63-64) - as presented in his habilitation thesis on Scheler - is perfectly aware that a phenomenologist reduces being to

3 On Wojtyła's methodology in the context of the Thomism-phenomenology confrontation, see, e.g. Kalinowski 1973-1974; Tischner 1973-1974; Szostek 1994; Buttiglione 1997: 72-82. Stępień (19731974: 153) calls Wojtyła's approach a 'Thomistic phenomenology'. 
a mere intentional entity which exists only as a content of acts of consciousness. ${ }^{4}$ Therefore, Wojtyła (1978: 107-108) offers instead a kind of fusion of Thomism with phenomenology to break the objectivism-subjectivism dichotomy. In result, he offers, e.g. to comprehend the act of consciousness in a Thomistic manner as actualization of real potentialities of a person (Wojtyła 1979a: 304), or to comprehend the human subject as 'suppositum humanum' (Wojtyła 1979b: 277).

In spite of these critical remarks, phenomenology provides a methodological framework for investigating experience. It is no exaggeration to claim that experience is the basic concept of Wojtyła's philosophy in general. As early as at the end of the 1940's, i.e. before his turn to phenomenology, Wojtyła - following St. John of the Cross, and his view of faith - puts emphasis on experience (e.g. Buttiglione 1997: 44-54; Gubser 2014: 197). Reference to experience is for Wojtyła a cornerstone of realistic philosophy. By 'experience' Wojtyła (1979a: 3-4; 1993: 108 ; 19) does not understand the 'purely sensory', but rather a subjective relation to the object. The relation is constituted as the process of understanding of what is experienced. To phrase it differently, experience is for Wojtyła the first-person access to what manifests itself, and for this reason experience involves self-experience, and self-knowledge at the same time (Holub, Mazur 2017: 75). If one experiences something, then, he or she comprehends the object from a unique, i.e. the first-person perspective. In Wojtyła's words, then, '[s]ubjectivity is the synonym of all that is irreducible in man' (Wojtyła 1978: 109). As such, however, the relation has a concrete character what means that it can be the object of further eidetic inquiries. What is investigated here, again, is not eidos comprehended as a non-worldly, and timeless entity, but the concrete experience. ${ }^{5}$

To conclude, it seems that the Thomistic approach is inactive in Wojtyła's analysis of solidarity for at least three reasons. First, the thesis that solidarity exists does not add anything to our understanding of solidarity. In this regard, one is not interested in the fact that solidarity exists, but rather in the ways it is experienced. Second, and more importantly, a Thomistic view of solidarity as actualization of potentialities leads towards a vicious circle, since it presupposes that solidarity is already established as a potentiality which is only actualized. Finally, Thomism paradoxically does not solve the bridge problem since it reduces solidarity to potentials of a man (cf. Płotka 2018: 169-170). In this context, a more promising way of analysing solidarity is phenomenology, which has a strong emphasis on experience. As stated, Wojtyła is skeptical about eidetic and transcendental methodological tools what leads him to the exclusion of eidetic variation, and reduction as justified methods. In turn, what he offers is rather a minimal phenomenology that consists in noticing and describing direct and intuitive experiences. It seems that this methodological approach enables one to ask about the ways of how solidarity is experienced. But this description is also made possible because of Wojtyła's social ontology.

${ }^{4}$ Szostek summarizes Wojtyła's critical elaboration of the Thomism-phenomenology confrontation in the following way: 'On the one hand, the Thomistic philosophy of being treats the problematics of morality in too objective manner at the cost of diminishing the subjective dimension which is so important for a philosophy of morality. On the other hand, the philosophy of consciousness which is represented by Scheler and the other phenomenologists excessively subjectivizes morality by isolating it from its real foundation in the human being' (Szostek 1994: 58). On Wojtyła's discussion with Scheler, see also Wojtyła 1976.

More on Wojtyła’s concept of experience, see Gozalez 2009: 135-138; Holub, Mazur 2017: 74-76. 


\section{A PERSON WITHIN COMMUNITY: A SKETCH OF WOJTYŁA'S SOCIAL ONTOLOGY}

For Wojtyła, a person is both an individual subject and the subject of a community. It is too hasty, however, to claim that community here is a mere set of individual subjects. Rather, the community unites persons (Wojtyła 1979a, 1979b). Wojtyła builds his social ontology on descriptions of personal and social experiences. Let us look closer at both factors.

Wojtyła's theory of the person is, of course, complex (e.g. Król 2017). In a general sense, the person is given in a special form of experience: namely, through the inner experience, which is manifested in action. So, 'action as the moment of special apprehension of the person always manifests itself through consciousness' (Wojtyła 1979a: 20). For Wojtyła, the person is manifested to him- or herself as existing and acting at the same time or, to phrase it differently, the person comprehends him- or herself as the subject of his or her actions. The person thus defined is a whole of concrete experiences, embodied ${ }^{6}$, and embedded in a community. The person is, then, an individual subject, which exists as the acting person. Moreover, actions and the person build a unity which cannot be divided into, e.g. a pure consciousness, and concrete actions. ${ }^{7}$ Wojtyła's key insight into the concept of the person is, as it seems, a radically dynamic view of the subject. Even more, since for Wojtyła the action 'is a new and superior type of dynamism' (Wojtyła 1979a: 197).

In his descriptions of the personal action, Wojtyła (1979a: 261-264) revels a unique form of experience, namely, acting 'together with the others'. Just as individual actions manifest the individual subject which exists as the acting person, joint actions manifest that the individual subject is always the subject of a community. ${ }^{8}$ In Wojtyła's words, '[t]he mark of the communal - or social - trait is essentially imprinted on human existence itself' (Wojtyła 1979a: 262). Wojtyła's concept of the community as instantiated in joint actions is crucial for understanding his account of sociality. For him, community is not a set of individual subjects who act on their own. This form of a group he labels 'the plurality of beings, of the acting subjects who are people' (Wojtyła 1979b: 289). By contrast, community is 'the specific unity of this multiplicity' (Wojtyła 1979b: 289). Thus, for Wojtyła, community is not a subject on its own, say, a higher-order subject which would be the subject of joint actions, but rather a way of grouping acting subjects who act 'together with the others'. In a word, community unites persons. In this regard, Wojtyła (1979b: 297-298) differentiates between (a) the interpersonal dimension, and (b) the social dimension of community. Whereas the former refers indirectly to 'I-thou' relation as the multiplicity of persons, and directly to the persons themselves, the latter refers directly to 'we', and indirectly to persons as the subjects of a community. So, community is constituted as 'we' in joint actions, which unite multiplicity of subjects. The community thus constituted, however, manifests itself not as a separate subject, but only through joint actions.

To summarize Wojtyła's social ontology, I highlight five of his observations: (a) community is expressed as 'we'; (b) community unities persons who (c) act together with the others;

6 Wojtyła (1979a: 196-206) writes about 'psychosomatic unity' which is possible because of person's actions.

7 Wojtyła explains that ' $[\mathrm{b}]$ etween the concrete human act and the particular self there exists a close causal and efficient connection. On the strength of this connection the act cannot be detached from the given self and ascribe to another as its author. The connection is quite different in kind from that between the human self and all that merely happens to it. We attribute the act, and hence conscious action, to this self as its conscious author' (Wojtyła 1979b: 280).

8 For recent studies in the phenomenon of joint actions, see Pacherie (2014) and Salmela and Nagatsu (2017) for discussion of Pacherie's account. 
(d) community is different than the interpersonal relation, which (e) consists in the 'I - thou' multiplicity of subjects. Wojtyła's social ontology conceives persons as strictly dynamic and acting subjects, however, community cannot be - in a strict sense - a subject of actions. As an alternative to the view of a community as a subject, Wojtyła (1979a: 277) advocates adverbial theory of community by stating that every community manifests itself by actions which are undertaken 'jointly' or 'together'.

\section{A PHENOMENOLOGY OF PARTICIPATION AS THE BASIS OF WOJTYŁA'S THEORY OF SOLIDARITY}

Wojtyła (1979a: 261-300) analyses the experience of participation in the fourth and last part of The Acting Person and he clearly emphasizes that his exposition is rather introductory, since the entire book is an attempt at personalism, and thus the main aim of this work is to construct a theory of the human being, and not of a community, or a society. Later, Wojtyła (1977, 1979b) developed his analysis to precise some theses. In any case, Wojtyła (1979a: 284-289) introduces his view of solidarity within the context of the phenomenon of participation. How, then, does Wojtyła describe participation?

According to Wojtyła, participation is a complex phenomenon, which is given in the experience of acting 'together with the others'. As such, however, it has an axiological structure since 'the performance itself of the action by the person is a value' (Wojtyła 1979a: 265). By claiming this, Wojtyła extrapolates from the results of his anthropological view of the person as strictly connected with the action. After all, as already claimed, actions and the person build a unity. The same holds for any community. Therefore, if community unites persons by acting jointly, or acting together with the others, it enables one to realize the value inherent in the action itself. ${ }^{9}$ What differentiates individual actions from joint actions is how someone experiences the action. Joint actions, namely, are experienced as 'our' actions, so - speaking phenomenologically - in modi 'we', as, e.g. in the case of 'we act together against violence'. 'The passage from multi-subjectivity - as Wojtyła (1979b: 305) puts it - to the subjectivity of all is the proper and full sense of the human "we"'. What is realized in these actions is what constitutes, and coordinates 'our' actions, i.e. 'our' aims, values, and tasks. ${ }^{10}$ Wojtyła (1979a: 280; 1979b: 305) calls this element the 'common good'. But, what makes this structure unique, and phenomenologically interesting is that one chooses the 'common good' as 'his own good and as the end of his own striving' (Wojtyła 1979a: 280). So, one acts 'together with the others', and experiences this acting as the realization of the 'common good', which, in turn, is comprehended as 'my own' good. Wojtyła's account of joint actions thus described seems to correspond with the phenomenological sense of we-agency of, e.g. 'sharing the same fate' or 'being in the same boat' (Salmela, Nagatsu 2017: 467).

In this very context, Wojtyła describes solidarity as 'a constant readiness to accept and to realize one's share in the community because of one's membership within that particular community' (Wojtyła 1979a: 285). So, 'to solidarize' means in the end 'to allow someone to partic-

9 'So far as acting itself is concerned, participation is responsible for the fact that the person acting together with others performs an action and fulfills himself in it' (Woityła 1979a: 269). In personalistic terms: 'Participation means the basic personalization of the relation of a human being to a human being' (Wojtyła 1977: 66). Wojtyła's account of responsibility in solidary actions with the others can be understood as 'shared responsibility', recently analysed by, e.g. Kolers (2016: 164-165).

${ }^{10}$ As Salmela and Nagatsu (2017: 458) put it: 'Collective commitment provides the group members group reasons to think, want, feel, and act in ways that are in accordance with their shared concern'. 
ipate in the community' and this is equivalent with acting 'together' or 'jointly'. In this sense, Wojtyła (1979a: 285) claims that solidarity manifests participation. Of course, the experience involves values and the 'common good', which all are constituted - as it seems - intersubjectively. From the first-person perspective, however, this intentional relation to intersubjective values is experienced as participation in the community, i.e. as acting 'together'. In a word, solidarity is here a unique attitude of the person or agent, who acts 'together' in order to realize the 'common good'. Following Wojtyła (1979a: 285): '[i]n accepting the attitude of solidarity man does what he is supposed to do not only because of his membership in the group, but because he has the "benefit of the whole" in view: he does it for the "common good".

\section{CONCLUSIONS}

This article has critically examined Wojtyła's early theory of solidarity in order to explore the limits and to investigate the possibilities of a phenomenology of solidarity. In doing so, this study provided a description of the first-person account of the experience of solidarity, i.e. of the act of solidarizing. At bottom, my intention was to reconstruct Wojtyła's view of how solidarity as a social phenomenon is experienced, or lived through. My ultimate aim was here to examine whether Wojtyła's proposal situates us beyond the bridge problem in the phenomenology of solidarity (cf. Płotka 2018). In conclusion, given Wojtyła's methodological background, the answer is twofold.

First, if one follows Wojtyła's Thomism, the bridge problem still holds. It is so, because by defining solidarity as a feature, or a trait of a human being, and at the same time as a trait of a community as a whole (e.g. Wojtyła 1979a: 271, 276), one cannot explain the shift from a subjective being to the intersubjective realization of solidarity. In a word, Wojtyła's Thomism does not account for a dynamic process of constituting groups. Moreover, one does not achieve anything by claiming that solidarity is possible due to the fact that a human being has the trait to actualize solidarity. Second, however, Wojtyła's minimal phenomenology - i.e. phenomenology, which does not employ the eidetic or transcendental reduction, but it instead describes experience as such - of solidarity omits the problem. Here Wojtyła's aim is to describe the ways of how solidarity is experienced. To do so, Wojtyła develops his adverbial social ontology. This theory can be summarized by pointing out that (a) community is expressed as 'we'; (b) community unities persons who (c) act together with the others; (d) community is different than the interpersonal relation which (e) consists in the 'I - thou' multiplicity of subjects. For Wojtyła, a community manifests itself by actions which are undertaken 'jointly' or 'together'. At this basis, solidarity is experienced as a unique way of letting one to participate in the community. Thus, in the end, Wojtyła's early theory of solidarity accounts for describing solidarizing as joint actions which aim at realization of 'our' aims, and values, whereas those values are comprehended as both 'my' good, and the 'common good'.

Received 11 February 2019 Accepted 20 May 2019

\section{References}

1. Burgos, J. M. 2009. 'The Method of Karol Wojtyła: A Way Between Phenomenology, Personalism and Methaphysics', Analecta Husserliana 104: 107-129.

2. Buttiglione, R. 1997. Karol Wojtyła: The Thought of the Man Who Became Pope John Paul II. Transl. by P. Guiettie and F. Murphy. Grand Rapids-Cambridge: William B. Eerdmans Publishing Company.

3. Carney, J. C. 2008. 'John Paul II: On the Solidarity of Praxis in His Political Philosophy', in Karol Wojtyla's Philosophical Legacy, eds. N. M. Billias, A. B. Curry, G. F. McLean. Washington D. C.: Council for Research in Values and Philosophy, 183-198. 
4. Doran, K. 1996. Solidarity: A Synthesis of Personalism and Communalism in the Thought of Karol Wojtyla/ Pope John Paul II. New York: Peter Lang.

5. Gonzalez, C. B. 2009. 'The Role of Experience in Karol Wojtiła's Ethical Thought', Analecta Husserliana 104: 131-146.

6. Gubser, M. 2014. The Far Reaches. Phenomenology, Ethics, and Social Renewal in Central Europe. Stanford: Stanford University Press.

7. Holub, G.; Mazur, P. S. 2017. 'The Experience of Human Being in the Thought of Karol Wojtyla', Filosofija. Sociologija 28(1): 73-83.

8. Johannes Paul II. 1988. Solidarität - die Antwort auf das Elend in der Enzyklika 'Sollicitudo Rei Socialis', Kommentar von Wilhelm Korff und Alois Baumgartner. Freiburg/Breisgau: Herder.

9. Kalinowski, J. 1973-1974. 'Metafizyka i fenomenologia osoby ludzkiej. Pytania wywołane przez Osobę i czyn', Analecta Cracoviensia 5-6: 63-71.

10. Kolers, A. 2016. A Moral Theory of Solidarity. Oxford: Oxford University Press.

11. Król, R. L. 2017. Karol Wojtyla's Philosophy of the Person. Truskaw: Sub Lupa Press.

12. Lesch, C. H. T. 2018. 'What Undermines Solidarity? Four Approaches and Their Implications for Contemporary Political Theory', Critical Review of International Social and Political Philosophy 21(5): 601615. DOI: 10.1080/13698230.2017.1398865.

13. McLean, G. F. 1994. 'Preface', in The Philosophy of Person: Solidarity and Cultural Creativity. Polish Philosophical Studies, I, eds. J. Tischner, J. M. Życiński, G. F. McLean. Washington, D. C.: Paideia Press \& The Council for Research in Values and Philosophy, vii-x.

14. Pacherie, E. 2014. 'How does It Feel to Act Together?', Phenomenology and the Cognitive Sciences 13(1): 25-46. DOI: 10.1007/s11097-013-9329-8.

15. Płotka, W. 2018. 'An Outline of a Phenomenology of Solidarity: Beyond the Bridge Problem', Filosofija. Sociologija 29(3): 167-175. DOI: 10.6001/fil-soc.v29i3.3773.

16. Salmela, M.; Nagatsu, M. 2017. 'How does It Really Feel to Act Together? Shared Emotions and the Phenomenology of We-agency', Phenomenology and the Cognitive Sciences 16(3): 449-470. DOI: 10.1007/ s11097-016-9465-z.

17. Schmale, W. 2017. 'European Solidarity: A Semantic History', European Review of History: Revue européenne d'histoire 24(6): 854-873. DOI: 10.1080/13507486.2017.1345869.

18. Stępień, A. B. 1973-1974. 'Fenomenologia tomizująca w książce Osoba i czyn', Analecta Cracoviensia 5-6: 153-157.

19. Stjernø, S. 2005. Solidarity in Europe. The History of an Idea. Cambridge: Cambridge University Press.

20. Szostek, A. 1994. 'Karol Wojtyla's View of the Human Person', in The Philosophy of Person: Solidarity and Cultural Creativity. Polish Philosophical Studies, I, eds. J. Tischner, J. M. Życiński, G. F. McLean. Washington, D. C.: Paideia Press \& The Council for Research in Values and Philosophy, 57-71.

21. Tiedemann, P. 2018. 'Solidarity', in Encyclopedia of the Philosophy of Law and Social Philosophy, eds. M. Sellers and S. Kirste. Dordrecht: Springer, 1-7. DOI: 10.1007/978-94-007-6730-0.

22. Tischner, J. 1973-1974. 'Metodologiczna strona dzieła Osoba i czyn', Analecta Cracoviensia 5-6: 85-89.

23. Wojtyła, K. 1976. 'The Intentional Act and the Human Act That Is, Act and Experience', Analecta Husserliana 5: 269-280.

24. Wojtyla, K. 1977. 'Participation or Alienation?', Analecta Husserliana 6: 61-73.

25. Wojtyła, K. 1978. 'Subjectivity and the Irreducible in Man', Analecta Husserliana 7: 107-114.

26. Wojtyła, K. 1979a. The Acting Person. Transl. from the Polish by A. Potocki, ed. A.-T. Tymieniecka. Dordrecht: D. Reidel Publishing Company.

27. Wojtyla, K. 1979b. 'The Person: Subject and Community', The Review of Metaphysics 33(2): 273-308.

28. Wojtyła, K. 1993. 'The Problem of Experience in Ethics', in K. Wojtyła, Person and Community. Selected Essays. Transl. by T. Sandok. New York: Peter Lang, 107-127.

29. Wojtyła, K. 2001. Zagadnienie podmiotu moralności, ed. T. Styczeń, J. W. Gałkowski, A. Rodziński, A. Szostek. Lublin: Towarzystwo Naukowe Katolickiego Uniwersytetu Lubelskiego.

30. Wojtyła, K. 2006. Wykłady lubelskie, ed. T. Styczeń, W. Chudy, J. W. Gałkowski, A. Rodziński, A. Szostek. 2nd edn. Lublin: Towarzystwo Naukowe Katolickiego Uniwersytetu Lubelskiego Jana Pawła II. 
WITOLD PŁOTKA

\section{Fenomenologija, bendruomenè, dalyvavimas: K. Wojtyłos ankstyvosios solidarumo teorijos kritinè analizè}

Santrauka

Kritiškai tyrinejama K. Wojtyłos ankstyvoji solidarumo teorija siekiant išsiaiškinti pagrindines jo vieningų veiksmų fenomenologijos sąvokas, metodus ir problemas. Remdamasis K. Wojtyłos ankstyvąja „solidarumo teorija“, W. Płotka išgrynina jo teoriją, suformuluotą Veikiančiame žmoguje ir su šia knyga susijusiose studijose, paskelbtose daugiausia aštuntajame dešimtmetyje. Autorius tvirtina, kad savo teorijoje K. Wojtyła pirmajjị asmenị apibūdina atsižvelgdamas ị solidarumo patirtį, solidarumą aiškina kaip socialinį fenomeną. Kitaip tariant, straipsnio tikslas - K. Wojtyłos solidarumo fenomenologija. W. Płotka pirmiausia tiria autoriaus metodologiją, t. y. tomizmą, jo fenomenologijos ir patirties sampratą, klausia, kuris metodologinis požiūris yra tinkamas apibūdinti solidarumą. Antra, yra rekonstruojama K. Wojtyłos socialinè ontologija. Jo teorija yra vertinama kaip veiksmo socialinè ontologija, nes joje žvelgiama ị bendruomenę kaip ị dinamišką struktūrą, kuri vienija tuos žmones, kurie veikia „kartu“. Galiausiai, W. Płotka išryškina pagrindinius autoriaus požiūrio ị dalyvavimą kaip socialinị fenomeną, grindžiantị solidarumą, akcentus.

Raktažodžiai: fenomenologinis metodas, bendruomené, socialinè ontologija, bendri veiksmai, personalizmas, Wojtyła 